\title{
Investigation of the Effects of Science, Technology and Society (STS) Education Based On Socioscientific Issues on Pre-Service Teachers' Science Literacy Levels*
}

\author{
Sosyobilimsel Konulara Dayalı Fen, Teknoloji ve Toplum Eğitiminin Öğretmen \\ Adaylarının Fen Okuryazarlık Seviyelerine Etkisinin Incelenmesi
}

\author{
Hatice Güngör Seyhan ${ }^{* *}$, Murat Okur ${ }^{* * *}$
}

\begin{abstract}
In the present study, the effect of Science, Technology and Society (STS) education conducted on socioscientific issues in "Science, Technology and Society" lesson on 83 pre-service science teachers' science literacy levels and attitudes towards socioscientific issues was examined. The design of the research is a singlegroup pre-test-post-test design, which is one of the quantitative research methods, which is a weak experimental design. Problem situations and possible solution suggestions for fourteen different socioscientific issues were designed and this implication that lasted 15 weeks were concluded. "Science Literacy Test" and "Attitude Scale towards Socioscientific Issues" was used as a data collection tool in the study. The data in the research were collected in the spring semester of the 2018-2019 academic year. The dependent sample t-test was used and it was observed that the relationship between the two variables was high level linear and positive in the analysis of the research. As a result of the research, it has been observed that all the implications carried out have caused positive changes in the science literacy and attitudes of the pre-service teachers towards socioscientific issues.
\end{abstract}

Keywords: Attitude of socioscientific issues, Science, technology and Society, Scientific Literacy, Socioscientific issues

Öz: Bu çalışmada, Fen, Teknoloji ve Toplum dersinde sosyobilimsel konularda gerçekleştirilmiş Fen, Teknoloji ve Toplum (FTT) eğitiminin, 83 fen bilgisi öğretmen adayının fen okuryazarlık düzeylerine ve sosyobilimsel konulara yönelik tutumlarına etkisi incelenmiştir. Araştırmanın deseni nicel araştırma yöntemlerinden zayıf deneysel desen türüne giren tek gruplu ön test -son test desendir. Veri toplama araçları olarak "Fen Okuryazarlık Testi” ve "Sosyobilimsel Konulara Yönelik Tutum Ölçeğì" kullanılmıştır. Araştırmadaki veriler, 2018-2019 eğitim-öğretim y1lı bahar döneminde toplanmıştır. Çalışmada 14 ayrı sosyobilimsel konuya yönelik problem durumları ve olası çözüm önerileri tasarlanmış ve 15 hafta süren uygulamalar sonuca ulaştırılmıștır. Verilerin analizinde, bağımlı örneklem t-testi kullanılmış ve iki değişken arasındaki ilişkinin yüksek düzeyde, doğrusal ve pozitif yönde anlamlı olduğu gözlenmiştir. Araştırma sonucunda gerçekleştirilen tüm uygulamaların öğretmen adaylarının fen okuryazarlıkları ve sosyobilimsel konulara yönelik tutumlarında olumlu yönde değişikliklere neden olduğu gözlenmiştir.

\footnotetext{
* This study was presented as an oral presentation at the 7th International Social Sciences Symposium (ASEAD 2021) and was included in the abstract proceedings book

${ }^{* * *}$ Assoc. Prof. Dr., Sivas Cumhuriyet University, Faculty of Education, Department of Chemistry Education, Sivas/Turkey. ORCID: 0000-0001-5116-7845, hgunsey@gmail.com

**** Assist.Prof. Dr., Sivas Cumhuriyet University, Faculty of Education, Department of Basic Education, Sivas/Turkey. ORCID: 0000-0003-2502-2276, okurmurat55@hotmail.com

Received/Geliş: 31 May/Mayıs 2020

Accepted/Kabul: 09 August/Ağustos 2021

Düzeltme/Revised form: 01 August/Ağustos 2021

Published/Yayın: 31 August/Ağustos 2021
}

e-ISSN: 2149-4622. (C) 2013-2019 Muş Alparslan Üniversitesi. TÜBİTAK ULAKBİM DergiPark ev sahipliğinde. Her hakk1 saklıdır. http://dx.doi.org/10.18506/anemon.946068 
Anahtar Kelimeler: Bilim, teknoloji ve toplum, fen okuryazarlığı, sosyobilimsel konular, sosyobilimsel konulara yönelik tutum

\section{Introduction}

Individuals in the society are expected to use technology and science effectively, and to interpret the possible effects of advances in these areas on themselves and their environment. The fact that developed countries in the field of science and technology are economically advanced has increased the interest in science education even more, and the goal of countries to make a more effective science education has gained importance (Zan Yörük, 2008). Therefore, when educational strategies are examined in many countries, it is aimed to have a society consisting of individuals who research, question, discuss, and produce, not to memorize the information given and answer when asked. In our country, fundamental reforms have been made in the education programs since 2004 and the education programs have changed according to the needs at various times.

Considering the aims of the Science Curriculum published in 2013, it is possible to create solutions to problems by adopting a scientific research approach in the exploration of the universe; to raise awareness of how science, society, and technology affect each other; to be aware of the relationship between individuals, society, and the environment, and to enhance sustainable development awareness related to natural resources; to use scientific process skills and other life skills in solving problems by taking responsibility for real-life problems; to develop curiosity, interest and attitude towards events occurring in nature; to gain and develop scientific thinking habits by using socioscientific issues (Ministry of National Education, MoNE, 2013). In this context, it is aimed to raise each person as individuals with scientific and/or science literacy in the Turkish Education System. It is of great importance how the science literate individual defines, combines, and evaluates the information in his/her mind. It is important for an individual with a developed science literacy to have enough knowledge to express his/her thoughts on science and socioscientific issues that concern society, to reach scientific information about these issues, to be able to interpret these information and to make decisions (Yavuz Topaloğlu \& Balkan Kıyıc1, 2017). Socioscientific issues are open-ended, complex, argumentative and poorly structured, with scientific and social dimensions (Gardner \& Jones, 2011; Klosterman, Sadler \& Brown, 2012; Ratcliffe \& Grace, 2003; Sadler \& Zeidler, 2005; Sadler, 2004; Sadler, Barab \& Scott, 2007, Sıbıç, 2017; Topçu, Sadler \& Yılmaz-Tuzun, 2010). Examples of socioscientific issues that are increasing day by day such as genetic replication, global warming, vaccines, nuclear power plants, hydroelectric power plants, GMO products (Topçu, 2015). With the introduction of nuclear power plants, discussions between those who support and oppose nuclear energy have also come to the fore in the society (Ercan, Ural \& Tekbiyık, 2015). In line with such contradictions, socioscientific issues concerning science and society have started to gain importance (Sadler, 2004). In order to raise the individual to this level of knowledge, it is of great importance to train individuals who can think creatively, notice the changes occurring in their environment, make logical decisions, have problem solving skills, and be a science literate. In this context, it is thought that with the development of students' ability to cope with socioscientific contradictions, their level of scientific literacy will also improve (Wu \& Tsai, 2011). This means that the development of decisionmaking skills in science-related socioscientific issues is believed to be an important part of science literacy, and socioscientific activities play an important role in the development of students' decisionmaking skills (Gülhan, 2012).

\section{The Importance of the Research}

Scientific literacy, which is defined as a process ranging from understanding the content and nature of science, being scientific, and the relationship between science-technology-society, to being able to interpret it, is one of the most important factors that activate the personality development process within the framework of social life (Turgut, 2005). Accordingly, scientific literacy brings new developments in the field of education in all countries of the world. Thus, the effect of science and technology on societies is increasing (Bacanak, 2002). It is emphasized that increasing the scientific literacy of the society is more necessary than the transfer of information (Tunç Şahin \& Say, 2010). The 
use of STS education at all grade levels in science education is of great importance because of the exact overlap between the scientific/science literacy aimed by science, technology and social education and the science literacy concept specified within the scope of the Programme for International Student Assessment (PISA). Current or historical local/national and global issues make science and technology understandable. As Genç (2020) stated in his study, improving the quality of life by selecting the contexts of "health", "natural resources", "environment", "dangers" and "the limits of science and technology" emphasized by PISA science literacy, in the light of students' interests and current lives, are areas of particular value in sustainability and public policy development (OECD, 2019). After 2013, MoNE started to integrate these socioscientific issues with science, technology and society (STS) education and Science course.

It has been stated that by handling socioscientific issues under the name of science lesson, students will make a better sense of many concepts, facts and events in this lesson and make them feel closer to this lesson (Pedretti, 1999). When the studies on socioscientific issues are examined as a whole, a student centred program is envisaged in the teaching of these subjects (Demirci \& Yüce, 2018; Gülhan, 2012; Ökkeşoğulları, 2021; Topçu \& Atabey, 2017). However, it is stated that socioscientific issues found a place in the 2013 Science course curriculum theoretically, but in practical terms, problems were experienced because they could not find sufficient place (Topçu, Muğaloğlu \& Güven, 2014). The curriculum (2018) updated by the MoNE on socioscientific issues has been examined and it has been observed that there are five gains at the 5th grade level, four gains at the 6thgrade level, three gains at the 7th grade level and eleven gains 8th grade level of the secondary school Science course. When the literature is examined, there are many studies emphasizing how important it is to cover socioscientific issues in the science course (Jimenez-Aleixandre \& Erduran, 2007; Ratcliffe \& Grace, 2003; Zeidler \& Sadler, 2005; Zeidler, Walker, Ackett \& Simmons, 2002; Zohar \& Nemet, 2002). Levinson (2006) emphasized that individuals who are confronted with socioscientific issues on the agenda need to use up-to-date information and personal experiences, and that their personal experiences should be taken into account in educating individuals on these issues. Since the subtopics included in socioscientific issues are problems related to daily life, explaining these topics and teaching students are among the main objectives of science education (Albe, 2008; Kolsto, 2006; Nielsen, 2012; Ökkeşoğulları, 2021; Walker \& Zeidler, 2007). Understanding socioscientific issues by students is seen as important in making decisions on issues that confront them in daily life and involving dilemmas, and what kind of processes and actions they use while making these decisions (Albe, 2008; Kolsto, 2006; Van der Zande, Warloo, Brekelmans, Akkerman \& Vermunt, 2011). In our country, there are many studies conducted with both higher education and secondary school students. It is noteworthy that most of the studies have been conducted in higher education (Benek, 2019; Birdal \& İnaltekin, 2019; Gülhan, 2012; Kaya, 2019; Yavuz-Topaloğlu \& Balkan-Kıyıc1, 2017; Yolagiden, 2017).

In this context, it is accepted as an absolute necessity to reveal the understanding of "science, technology and society" within the scope of the STS course held on socioscientific issues in their faculties of prospective teachers who will become teachers of the Science Course in the future. On the other hand, there are studies emphasizing that STS course is appropriate in terms of content in order to develop students' science literacy and to develop positive attitudes towards socioscientific issues planned to be given within the course, but more empirical studies should be included (Bacanak, 2002; Turgut, 2005; Yalaki, 2014; ZanYörük, 2008).

\section{Purpose of the Research}

In present study, an educational environment in which socioscientific issues are discussed in the "Science, Technology and Society" course was created with 83 pre-service teachers studying in the last semester in the Science Education Department. The "Science, Technology and Society" course started to be applied in related faculties for the first time in 2001-2002 academic years. The aim of the STS course was determined as "the expected characteristics of individuals with advanced science literacy and the importance of the relationship between science teaching and the role of teachers and science, technology and society in order to achieve these characteristics". Some learning areas and related concepts consisting of socioscientific issues that will help to develop science literacy in the content of 
science, technology and society lessons are stated as follows (Bacanak, 2002): Biosphere and universe (global warming, acid rain, ozone depletion, etc.); the changing world (the formation of the earth, how maps are drawn, the formation of continents, glaciers and mountains, and the way humanity shows them (mapping), etc.); illness and health (a historical overview of disease-related problems, known and common diseases, etc.); radiation (obtaining energy from radiation, where radiation is used in nature, Chernobyl, etc.); genes (Mendel and his laboratory, his experiments in Czechoslovakia, Watson and Crick DNA model, chromosome, replication, etc.); nuclear power (history of nuclear research and studies of nuclear research centers, the origin of radiation, Chernobyl, fission / fusion, hydrogen bomb, Nagazaki, radioactive waste, etc.); energy and society (past and future of energy, limitations in meeting the needs of near and far future societies, agricultural revolution, industrial revolution, nuclear energy, acid rain, greenhouse effect, ozone depletion problem, renewable energy sources, etc.). The determination of the science literacy levels and attitudes towards socioscientific issues of the pre-service teachers who are engaged with the implications in this course and the effects of the implications they are engaged in on the relevant variables were examined within the scope of the study.

\section{Method}

\section{Research Model}

In the study, single-group pre-test-post-test design, which is one of the quantitative research methods, which is a weak experimental design was used. In this research design, all implications are carried out with a single group. The measurements of the subjects related to the dependent variable are obtained by using the same subjects and the same measurement tools as the pre-test before the implications and the post-test after the implications (Büyüköztürk et al., 2009, p.198).

\section{Study Group}

The target population of the sample is composed of pre-service teachers studying at the Department of Science Education who will become science teachers in the near future. The sample is composed of 83 pre-service teachers studying in Faculty of Education, Department of Science Education in 4th grade in the fall semester of the 2018-2019 academic years.

\section{Data Collection Tools}

\section{Science Literacy Test (SLT)}

The Science Literacy Test used within the scope of the study is a 25 question multiple choice test developed by Bacanak (2002) during his PhD study. The questions in the test were prepared as 30 questions in the light of the information gathered about science literacy, science, technology, society, and environment education and course content. After the validity and reliability analysis, the test was finalized. After the pilot study of the test, the Pearson correlation coefficient was determined to be 0.76 . Sample item for the science literacy test are as follows:

Items-1 Exhaust gases from the exhausts of cars are more common in winter than in summer days. Which of the following is the most important reason for this?

a- Cars burn more gas on winter days.

b- On winter days, cold air intensifies the air coming out of the exhaust more.

c- Chemical substances added to gasoline appear more clearly on winter days.

d- More exhaust gas is released due to the antifreeze used to prevent freezing in winter days.

e- Since the combustion reaction is faster in cold weather, more gas comes out.

\section{Attitude Scale towards Socioscientific Issues (ASSI)}

In the study, "Attitude Scale to Socioscientific Issues" developed by Topçu (2010) was used. The scale consists of 3 sub-dimensions and 30 items. As a result of the exploratory and confirmatory factor analyses performed for this five-point Likert-type scale, it was revealed that the scale was collected in 3 dimensions with Cronbach alpha internal reliability coefficients varying between 0.70-0.90. Sample items for the socioscientific issues scale are as follows:

Item-9 Socioscientific issues have a very important place in daily life, 
Item-21 I like trying to understand the events happening in my environment using the information I have learned about socioscientific issues,

Item-29 I think that social values will be damaged in practices about socioscientific issues.

\section{Implications Process}

All implications in the study were carried out within the scope of STS course. Pre-service teachers worked in groups during the process. At the beginning of the implications, pre-service teachers were asked to create problem situations reflecting real-world problems related to socioscientific issues of STS course. For this, pre-service teachers were given two-week period to do all the necessary research. During the next two weeks (Presentation weeks-I), the designed problem situations and possible solutions (at least three solution suggestions) for these problem situations were presented to other preservice teachers and researchers. In the next two weeks, possible solutions were discussed under the guidance of the researchers. All resources that fall under the relevant expertise of the designed problem situations were consulted (experts in their fields, written and visual resources, web, government/private institution officials, etc.). After the best possible solution proposal was determined, the solution phase of the designed problem situation was started. The group report, which was prepared to reflect the whole process very well, was presented in the last two weeks (Presentation weeks-2).

\section{Analysis of Data}

For this reason, some analyses were made to determine the statistical method to be applied to the data obtained from SLT, ASSI and Performance grade, and it was examined whether the scores showed a normal distribution or not. After the normal distribution of the distribution of data collection tools preand post-test data obtained from our study was determined, t-test for the dependent groups which is one of the parametric tests and multiple linear regression analysis.

\section{Findings}

\section{Findings from the Normal Distribution of Data Collection Tools Pre- and Post-Tests}

It was examined whether the scores that ASSI, SLT and performance grade, showed a normal distribution or not in the scope of this study.

Table 1. Normality Test for Performance Grade, SLT and ASSI Pre- and Post-tests of PreService Teachers

\begin{tabular}{llcccc}
\hline & Perf. & $\begin{array}{c}\text { SLT } \\
\text { (Pre-) }\end{array}$ & $\begin{array}{c}\text { SLT } \\
(\text { Post-) }\end{array}$ & $\begin{array}{c}\text { ASSI } \\
\text { (Pre- }\end{array}$ & $\begin{array}{c}\text { ASSI } \\
\text { (Post- }\end{array}$ \\
\hline Valid & 83 & 83 & 83 & 83 & 83 \\
\hline Mean & 80.96 & 53.59 & 67.78 & 3.25 & 3.43 \\
\hline $\begin{array}{l}\text { Std. } \\
\text { Deviation }\end{array}$ & 6.07 & 9.89 & 7.77 & .10 & .14 \\
\hline Skewness & .33 & -.01 & -.21 & .03 & -.18 \\
\hline $\begin{array}{l}\text { Std. } \\
\text { Error of } \\
\text { Skewness }\end{array}$ & .26 & .26 & .26 & .26 & .26 \\
\hline Kurtosis & -.22 & .19 & -.20 & -.06 & -1.09 \\
\hline $\begin{array}{l}\text { Std. } \\
\text { Error of } \\
\text { Kurtosis }\end{array}$ & .52 & .52 & .52 & .52 & .52 \\
\hline
\end{tabular}

Statistics value / Std. error value is found for Skewness and Kurtosis. The resulting value is expected to be between -2 and +2 for normality. However, there are also publications that accept -3 and +3 (Tabachnick, Fidell, \& Ullman, 2007; McKillup, 2011; Wilcox, 2011; Howitt \& Cramer, 2011; Lind, Marchal \& Wathen, 2006). Skewness statistical values for Performance (1.269), SLT (Pre-) (-0.038), SLT (Post-) (-.807), ASSI (Pre-) (.115) and ASSI (Post-) (-.692) are the values obtained by dividing by the standard error. Kurtosis for Performance (- .423), SLT (Pre-) (0.365), SLT (Post-) (-.384), ASSI (Pre-) (-.115) and ASSI (Post-) (-.2.09) are the values obtained by dividing the statistical values by the standard error. When the data in Table 1 are examined, that the Kurtosis and Skewness values are within 
the range of \pm 2 indicates that all data in the SLT and ASSI pre and post-tests of the pre-service teachers participating in the study are suitable for normal distribution. Mayers (2013, p.53) recommends that a threshold value of \pm 1.96 should be used for samples less than 50 , a threshold value of \pm 2.58 for samples from 51 to 100 , and a threshold value of \pm 3.29 for samples greater than 100 . Since the pre-service teachers participated in the study consisted of 83 people, we can say that Performance 1.269 complies with the normality assumption. However, evaluations must be made together with the histogram.

Table 2. Kolmogorov-Smirnov Test for SLT and ASSI Pre- and Post-test and Performance Grade

\begin{tabular}{llllr}
\hline & \multicolumn{4}{c}{ Kolmogorow-Smirnov } \\
\hline \multirow{2}{*}{ Performance } & & Statistics & df & $\boldsymbol{p}$ \\
\hline \multirow{2}{*}{ Pre-test } & .06 & 83 & .184 \\
\hline \multirow{2}{*}{ Post-test } & SLT & .15 & 83 & .000 \\
\cline { 2 - 5 } & ASSI & .08 & 83 & .200 \\
\cline { 2 - 5 } & SLT & .10 & 83 & .049 \\
\hline
\end{tabular}

a. Lilliefors Significance Correction

*. This is a lower bound of the true significance.

Also, in cases where the group size is greater than 50, it is checked whether the normality assumption is met by looking at the value of Kolmogorow-Smirnov (Tabachnick, Fidell, \& Ullman, 2007).

If $\mathrm{p}>.05$ is obtained in Shapiro Wilk and/or Kolmogorov Smirnov tests, the distribution is normal, if a $\mathrm{p}<.05$ value is obtained, the distribution is not normal (Howitt \& Cramer, 2011; Lind, Marchal, \& Wathen, 2006; Tabachnick, Fidell, \& Ullman, 2007; McKillup, 2011; Wilcox, 2011). According to these values, SLT (pre- and post-tests) results in the Kolmogorov-Smirnov test show non-normal distribution, while Performance, ASSI (pre- and post-test) shows normal distribution. The results in the KolmogorovSmirnov test show that we encounter both normal and non-normal data. However, when we look at the QQ Plot and Histogram Analysis, we can say that all of the Performance, SLT (pre- and post-tests) and ASSI (pre- and post-tests) results can show the assumption of normality, especially from the Q-Q plots.

In these conditions, it would be more accurate to perform analyse with parametric tests suitable for normal distribution. Kolmogorov-Smirnov test may give false positive results. In addition, outlier data were not excluded while performing these analyses. The tests to be performed by removing the Outlier data from the analysis will increase the reliability of the normality assumption.

\section{Findings from the Science Literacy Test (SLT) and the Attitude Scale towards Socioscientific Issues (ASSI)}

In the study, t-test was performed for dependent groups in comparison of SLT and ASSI (pre-test and post-test) results (Table 3).

Table 3. Findings from the SLT and ASSI

\begin{tabular}{lllllll}
\hline SLT & $\mathbf{N}$ & $\mathbf{x}$ & $\mathbf{s}$ & $\mathbf{t}$ & $\boldsymbol{p}$ \\
\hline Pre-test & 83 & 53.59 & 9.89 & & -13.48 & .000 \\
\cline { 1 - 4 } Post-test & 83 & 67.78 & 7.77 & & \\
\hline ASSI & & & & & \\
\cline { 1 - 4 } Pre-test & 83 & 3.25 & .10 & & -17.40 & .000 \\
\cline { 1 - 4 } Post-test & 83 & 3.44 & .14 & & \\
\hline
\end{tabular}


As a result of these implications, it was determined that there was a statistically significant increase in the science literacy levels $(\mathrm{t}(83)=-13.48, \mathrm{p}<0.05)$ and in the attitude levels of towards socioscientific issues $(\mathrm{t}(83)=-17.40, \mathrm{p}<0.05)$ of pre-service teachers. This findings show that practices based on the "Science, Technology and Society" education have an important effect on increasing preservice teachers' science literacy levels and attitudes towards socioscientific issues.

\section{Statistical Analysis of Results Obtained from SLT and ASSI}

Multiple linear regression analysis was conducted to examine how much the SLT and ASSI posttest results of the pre-service teachers who participated in the implications carried out within the scope of the STS course together predicted the performance of the pre-service teachers.

Table 4. Descriptive Statistics

\begin{tabular}{llll}
\hline & Mean & Std. dev. & N \\
\hline Performance & 80.96 & 6.07 & 83 \\
\hline SLT_Post-test & 67.78 & 7.77 & 83 \\
\hline ASSI_Post-test & 3.44 & .14 & 83 \\
\hline
\end{tabular}

This table shows us the arithmetic mean and standard deviations of our variables that we included in the model.

Table 5. Model Summary

\begin{tabular}{llll}
\hline Model & $\mathbf{R}$ & $\mathbf{R}^{2}$ & Corrected $\mathbf{R}^{2}$ \\
\hline 1 & $.81^{\mathrm{a}}$ & .65 & .64 \\
\hline
\end{tabular}

The $\mathrm{R}^{2}$ value given in Table 5 shows what percentage of the dependent variable is explained by the independent variables.

It is shown in Table 5 that $65 \%$ of the change in the performance of the pre-service teachers that occur at the end of the implications is explained together by science literacy levels and the attitude variables towards socioscientific issues of the pre-service teachers that we included in the model. The remaining $35 \%$ is explained by the variables that we do not include in the model by means of the error term.

Table 6. Variance Analysis Table

\begin{tabular}{|c|c|c|c|c|c|}
\hline Model & $\begin{array}{l}\text { Sum of } \\
\text { Squares }\end{array}$ & df & $\begin{array}{l}\text { Mean } \\
\text { of } \\
\text { Squares }\end{array}$ & $\mathbf{F}$ & $p$ \\
\hline 1Regression & 1962.08 & 2 & 981.04 & 73.98 & $.000^{\mathrm{a}}$ \\
\hline Rest & 1060.81 & 80 & 13.26 & & \\
\hline Total & 3022.89 & 82 & & & \\
\hline
\end{tabular}

bependent Variable: Performance

The value of $F=73.98$ shows that our model as a whole is significant at all levels $\left(R=.81, R^{2}=\right.$ $.65, \mathrm{p}=.000)$. 
Table 7. Table of Coefficients

\begin{tabular}{|c|c|c|c|c|c|}
\hline \multirow[t]{2}{*}{ Model } & \multicolumn{2}{|c|}{$\begin{array}{l}\text { Non-std. } \\
\text { coefficients }\end{array}$} & \multirow{2}{*}{$\begin{array}{l}\begin{array}{l}\text { Std. } \\
\text { coeff. }\end{array} \\
\beta\end{array}$} & \multirow[t]{2}{*}{$\mathbf{t}$} & \multirow{2}{*}{$p$} \\
\hline & B & Std.err & & & \\
\hline 1Const. & 12.68 & 10.97 & & 1.16 & .251 \\
\hline $\begin{array}{l}\text { SLT } \\
\text { Post-test }\end{array}$ & .47 & .076 & .61 & 6.26 & .000 \\
\hline $\begin{array}{l}\text { ASSI } \\
\text { Post-test }\end{array}$ & 10.52 & 4.11 & .25 & 2.56 & .012 \\
\hline
\end{tabular}

According to the standardized regression coefficient $(\beta)$, the order of relative importance of predictive variables on pre-service teachers' performance is science literacy and then attitude levels towards socioscientific issues.

When the t-test results regarding the significance of the regression coefficients were examined together, it was seen that the variable of science literacy level and attitude levels towards socioscientific issues was a significant predictor of performance. While $65 \%$ of the change in the performance of preservice teachers participating in implications based on the STS education within the scope of the STS course was explained by the independent variables that we included in the model, the correlation coefficient was calculated to understand the relationship between the independent variables and the direction of this relationship (Table 8).

Table 8. The Correlation Results between SLT and ASSI (post-test)

\begin{tabular}{llll}
\hline & & SLT_PT & ASSI_PT \\
\hline SLS_Post- & Pearson & 1 & $.730^{*}$ \\
test & Correlation & & .000 \\
& $p$ & & \\
\hline ASSI_Post- & Pearson & .730 & 1 \\
test & Correlation & .000 & \\
& $p$ & & \\
\hline *Correlation is significant at the 0.01 level
\end{tabular}

When Table 8 is examined for the result of correlation analysis, it is seen that there is a $1 \%$ significance level correlation between pre-service teachers' science literacy and their attitude level towards socioscientific issues. Accordingly, it is observed that there is a high level, positive and significant relationship with 0.730 between pre-service teachers' science literacy and their attitude level towards socioscientific issues.

\section{Results and Discussion}

Within the scope of the study, the effect of the "Science, Technology and Society" education practices carried out by the pre-service science teachers within the scope of the last year Science, Technology and Society course on their levels of science literacy, and their attitudes of socioscientific issues were investigated. The relations of the mentioned variables with each other were examined.

This study showed that the science literacy levels of pre-service science teachers were slightly above the mean value. There are studies showing that pre-service teachers' science literacy is at low and medium level in studies conducted considering the scope of STS course or based on STS education (Bacanak, 2002; Huyugüzel Çavaş, 2009; Kocabaş, 2004; Yolagiden, 2017; Zan Yörük, 2008). The 
quality of education and the effect of the courses taken on the development of science literacy of preservice science teachers can be mentioned. In the literature, it was concluded that science literacy levels of pre-service teachers improved positively after the implications carried out within the scope of the "Science, technology and society" course (Kocabaş, 2004; Zan Yörük, 2008). In another study examining the effect of "STS" education on the science and literacy levels of pre-service science teachers, it was concluded that the content of the STS course was insufficient and there was no significant relationship between science literacy and course achievement averages. In this study, it is stated that there are deficiencies in the necessary tools and equipment to be used in the course; preservice teachers cannot adapt to interactive methods, and this result was reached due to the lack of time and means (Bacanak, 2002).

It has been observed that studies focusing on socioscientific issues in science education have increased rapidly in our country. When this studies on socioscientific issues in science education are examined, 17 postgraduate theses have been reached since 2012. It has been observed that there are studies in which variables such as the level of knowledge of university students in socioscientific issues, their perceptions, the effectiveness of various methods and techniques used in teaching socioscientific issues. In these studies, it was observed that students' opinions about these educational environments, self-efficacy perceptions and attitude levels towards socioscientific issues. In most of the postgraduate studies examined, it was observed that argumentation and informal reasoning skills were examined in the teaching of socioscientific issues. After 2013, the MoNE included the acquisitions of socioscientific issues in the Science lesson curriculum, and diversity was observed in the education level of the participants who participated in the studies on this subject. In present study, an educational environment in which socioscientific issues were discussed with students studying at university level was created. The students, who are candidates to become a teacher of the Science lesson, which the MoNE has frequently included in the teaching of these subjects since 2013, were busy with the problems and possible solution suggestions they created regarding socioscientific issues and worked actively with their group mates in a period of 15 weeks. They have successfully completed many important projects, from the effort to raise awareness about the ability of HIV+ people to live safely with other normal individuals in the society, to the process of minimizing the environmental damage of the greenhouse effect caused by chemical and improper fertilization, to the production of natural fertilizers from domestic wastes. The pre-service teachers tried to reduce the negative effects of continuous exposure to electromagnetic radiation such as radio waves, microwaves and/or visible light due to the technological equipment used in the home, and designed the relevant sensor-supported equipment for this. In order to reveal the importance of projects such as CERN in the teaching of atomic and subatomic particles, the pre-service teachers examined the active working processes of all Science centers serving nationally and made designs on what can be done about the atom. Since socioscientific issues are constantly encountered, they should be addressed together with science education. In this direction, attitude towards socioscientific issues is becoming more important day by day. In this study, the attitudes of preservice teachers' towards socioscientific issues were examined and according to the findings, it was observed that the attitudes of pre-service teachers towards socioscientific issues were above the middle level. In the analyses conducted, it was found that there was a statistically significant increase in the attitude levels of pre-service teachers towards socioscientific issues after these implications $(t(83)=-$ $17.40, \mathrm{p}<0.05)$. It can be said that present finding is the expected result, after the pre-service teachers dealt with the problem situations in socioscientific issues that concern the society they live in, from the very beginning of the 15 -week process. The pre-service teachers stated that the insufficiency of pedagogical field knowledge about the problem situations they posed disturbed them very much. They stated that they had a very productive process especially in the "scientific research" stage, which is the most important stage of the process, especially in communication with experts in the relevant subject (e-mail, face-to-face meetings, appointments with officials of official institutions, etc.). For example, a group of pre-service teachers have been busy developing solution suggestions for the problem situation to show the "environmental damage caused by batteries thrown into nature unconsciously" belonging to the "toxic waste" learning area. During the solution proposal process of this problem situation, the pre-service teachers contacted official institutions and gained knowledge and experience about the use and importance of instrumental analysis methods such as "heavy metal analysis in soil", which they 
have never experienced before. In the interviews conducted with the pre-service teachers about the process of teaching the STS course after the implications, their expressions like they should give more importance to the pedagogical field knowledge that they felt lacking throughout the process, and they realized how effective all the courses they took under the discipline of physics, chemistry and biology throughout their undergraduate education were effective in solving problems related to socioscientific issues are perhaps the most important finding of the study. "It has been observed that pre-service teachers' self-efficacy levels have a self-efficacy above the mean value in teaching subjects such as "Genetically modified organisms" (Baltac1, 2013; Qin \& Brown, 2007). In another study, the attitude levels of classroom and pre-service science teachers towards socioscientific issues were examined and it has been determined that the attitude levels of pre-service teachers in both disciplines towards socioscientific issues are moderate (Yolagiden, 2017).

In this study, it is seen that the relationship between pre-service teachers' science literacy and their attitudes towards socioscientific issues is high level, linear and positive. According to this, it can be said that as the science literacy of pre-service teachers increases, their attitudes towards socioscientific issues will also increase. In summary, it was observed that all activities carried out within the scope of the relevant education caused positive changes in pre-service teachers' science literacy levels and attitudes towards socioscientific issues.

\section{Disclosure Statements}

1. Contribution rate statement of researchers: First author \% 50, Second author $\% 50$.

2. No potential conflict of interest was reported by the authors.

\section{References}

Albe, V., (2008). When scientific knowledge, daily life experience, epistemological and social considerations intersect: Students' argumentation in group discussions on a socioscientific issue. Research in Science Education, 38(1), 67-90. doi:https://doi.org/10.1007/s11165-007-9040-2.

Bacanak, A., (2002). A study about the evaluation of the science student teachers' scientific literacy and application of science-technology-society course (MSc. Thesis), Karadeniz Technical University, Institute of Science, Trabzon.

Baltaci, S., (2013). Pre-service science teachers teaching efficacy beliefs about a socioscientific issue (GM foods) and the relationships between efficacy beliefs and epistemological beliefs (Unpublished MSc. Thesis), Abant İzzet Baysal University, Institute of Education Sciences, Bolu.

Benek, İ., (2019). Examination of the effect of socioscientific STEM's activities on students' attitudes and 21st century skills, Istanbul University, Cerrahpaşa Graduate Educatıon Instıtute, Istanbul.

Birdal, H.A., \& İnaltekin, T., (2019). The effect of argument-based learning applications on the development of pre-service science teachers' student comprehension knowledge about socioscientific issues, EKEV Akademi Dergisi, 23(80), 263-301.

Büyüköztürk, Ş., Çakmak, E.K., Akgün, Ö.E., Karadeniz, Ş., \& Demirel, F., (2010). Scientific research methods. Ankara: Pegem Publishing.

Demirci, M., \& Yüce, Z., (2018). Experimental planning on teaching of biotechnology and genetic engineering for 8th grade students. Journal of Sakarya University Faculty of Education, (35), 87108.

Ercan, O., Ural, E., \& Tekbiyık, A., (2015). Pre-service teachers' attitudes towards nuclear energy and the effect of Fukushima nuclear disaster on their attitudes. The International Journal of Social Sciences and Humanities Invention, 2(11), 1669-1678. 
Gardner, G., \& Jones, G., (2011). Perceptions and practices: Biology graduate teaching assistants' framing of a controversial socioscientific issue, International Journal of Science Education, 33(8), 1031-1054.

Genç, M.N., (2020). An examination of assessment and evaluation activities in a Turkish eighth-grade science textbook, according to international student assessment science literacy proficiency levels (PISA) (Unpublished MSc. Thesis), Yıldiz Technical University, Institute of Science, Istanbul.

Gülhan, F., (2012). The investigation about the effect of argumentation on socioscientific issues in scientific literacy for eighth grade students, tendency in the argumentation, decision making skills and science-social problems of sensitivity (Unpublished MSc. Thesis), Marmara University, Institute of Education Sciences, Istanbul.

Howitt, D., \& Cramer, D., (2011). Introduction to SPSS statistics in psychology: for version 19 and earlier. Pearson.

Huyugüzel-Çavuş, P.H., (2009). The investigation of elementary teachers? Science and technology literacy and their competence in science teaching (PhD Thesis), Dokuz Eylül University, Institute of Education Sciences, Izmir.

Jiménez-Aleixandre, M.P., \& Erduran, S., (2007). Argumentation in science education: An overview. In Argumentation in science education, 3-27. doi:https://doi.org/10.1007/978-1-4020-6670-2_1.

Kaya, M., (2019). The effect of socio- scientific issue based science education on 7 th grade students' scientific literacy and environmental literacy levels (Unpublished MSc. Thesis), Mersin University Institute of Education Sciences, Mersin.

Klosterman, M.L., Sadler, T.D., \& Brown, J., (2012). Science teachers' use of mass media to address socioscientific and sustainability issues, Research in Science Education, 42(1), 51-74.

Kocabaş, Ö., (2004). The effect of science technology society course to the science student teachers and the student teacher's attitude about science technology society (STS) course (MSc. Thesis), Gazi University, Institute of Education Sciences, Ankara.

Kolstø, S.D., (2006). Patterns in students' argumentation confronted with a risk focused socioscientific issue. International Journal of Science Education, 28(14), 1689-1716. doi:https://doi.org/10.1080/09500690600560878.

Levinson, R., (2006). Towards a theoretical framework for teaching controversial socioscientific issues, International Journal of Science Education, 28(10), 1201-1224.

Lind, D.A., Marchal, W.G., \& Wathen, S.A., (2006). Basic statistics for business \& economics. Boston: McGraw-Hill/Irwin.

Mayers, A., (2013). Introduction to statistics and SPSS in psychology. Harlow: Pearson Education Limited.

McKillup, S., (2011). Statistics explained: An introductory guide for life scientists. Cambridge University Press.

Ministry of National Education-MoNE, (2013). Elementary science course curriculum and guide. Ankara: Board of Education and Discipline. URL (Available date: 27.05.2021) http://ttkb.meb.gov.tr/program2.aspx?islem=1\&kno=213.

Nielsen, J.A., (2012). Science in discussions: An analysis of the use of science content in socioscientific discussions. Science Education, 96(3), 428-456. doi:https://doi.org/10.1002/sce.21001.

OECD, (2019). What can students do in science? PISA 2018 results (Vol.I): What students know and can do (s.111-117), in Paris: OECD Publishing. https://doi.org/10.1787/5f07c754-en. 
Ökkeşoğulları, E., (2021). Examination of mental qualities and attitudes on 8th grade students to socioscientific topics (Unpublished MSc. Thesis), Tokat Gaziosmanpaşa University, Institute of Education Sciences, Tokat.

Pedretti, E., (1999). Decision making and STS education: Exploring scientific knowledge and social responsibility in schools and science centers through an issues-based approach. Journal of School Science and Mathematics, 99(4), 174-181.

Qin, W., \& Brown, J.L., (2007). Public reactions to information about genetically engineered foods: Effects of information formats and male/female differences. Public Understanding of Science 16(4), 471-488.

Ratcliffe, M., \& Grace, M., (2003). Science education for citizenship: Teaching socioscientific issues. Maidenhead: Open University Press.

Sadler, T.D., Barab, S.A., \& Scott, B., (2007). What do students gain by engaging in socioscientific inquiry? Research in Science Education, 37(4), 371-391. doi:https://doi.org/10.1007/s11165-0069030-9.

Sadler, T.D., (2004). Informal reasoning regarding socioscientific issues: A critical review of research. Journal of Research in Science Teaching, 41(5), 513-536.

Sadler, T.D., \& Zeidler, D.L., (2005). The significance of content knowledge for informal reasoning regarding socioscientific issues: Applying genetics knowledge to genetic engineering issues. Science Education, 89(1), 71-93.

Sibıç, O., (2017). Pre-service science teachers' views towards socioscientific issues and socioscientific issue based instruction (Unpublished MSc. Thesis), Institute of Science, Y1ldiz Technical University, Istanbul.

Tabachnick, B.G., Fidell, L.S., \& Ullman, J.B., (2007). Using multivariate statistics (Vol.5). Boston, MA: Pearson.

Topçu, M.S., (2015). Socioscientific issues and teaching. Ankara: Pegem Publishing.

Topçu, M.S., \& Atabey, N., (2017). The effect of socioscientific issues based field trips on elementary school students' argumentation quality. Bartın University Journal of Faculty of Education, 6(1), 68-84.

Topçu, M.S., Muğaloğlu, Z.E., \& Güven, D., (2014). Socioscientific issues in science education. Educational Sciences: Theory \& Practice, 14(6), 2327-2348.

Topçu, M.S., (2010). Development of attitudes towards socioscientific issues scale for undergraduate students. Evaluation \& Research in Education, 23(1), 51-67.

Topçu, M.S., Sadler, T.D., \& Yilmaz-Tuzun, O., (2010). Pre-service science teachers' informal reasoning about socioscientific issues: The influence of issue context. International Journal of Science Education, 32(18), 2475-2495. doi:https://doi.org/10.1080/09500690903524779

Tunç Şahin, C., \& Say, Ö., (2010). Investigation of scientific literacy levels of elementary students. Zonguldak Karaelmas University ZKU, Journal of Social Sciences, 6(11), 223-240.

Turgut, H., (2005). The effect of constructivist design application on prospective science teachers' scientific literacy competence improvement at the dimensions of nature of science and sciencetechnology-society interaction (MSc. Thesis), Yıldız Technical University, Institute of Social Science, Istanbul.

Walker, K.A., \& Zeidler, D.L., (2007). Promoting discourse about socioscientific issues through scaffolded inquiry. International Journal of Science Education, 29(11), 1387-1410, doi: https://doi.org/10.1080/09500690601068095. 
Wilcox, R., (2011). Modern statistics for the social and behavioural sciences: A practical introduction. CRC press.

Wu, Y.T., \& Tsai, C.C., (2011). High school students' informal reasoning regarding a socioscientific issue, with relation to scientific epistemological beliefs and cognitive structures. International Journal of Science Education, 33(3), 371- 400. doi:https://doi.org/10.1080/09500690903505661.

Yalaki, Y., (2014). What is the status of science, technology, society, environment (STSE) education in Turkey? Cito Education: Theory and Practice, 26, 27-36.

Yavuz-Topaloğlu, M., \& Balkan-Kıyıcı, F., (2017). The effect of hydroelectric power plants trip on students' conceptual understandings, Mersin University (MEÜ) Journal of Faculty of Education, 13(3), 1151-1172. doi:https://doi.org/10.17860/mersinefd.332502.

Yolagiden, C., (2017). Examination of the relationship between prospective teacher's attitudes towards science learning skills, science literacy and social scientific issues (Unpublished MSc. Thesis), Kahramanmaraş Sütçü İmam University, Institute of Education Sciences, Kahramanmaraş.

Zan Yörük, N., (2008). Effects of science, technology, society and environment (STSE) approach teaching chemistry with using the 5E learning model ( $\mathrm{PhD}$ Thesis), Institute of Science, Hacettepe University, Ankara.

Zeidler, D.L., Walker, K.A., Ackett, W.A., \& Simmons, M.L., (2002). Tangled up in views: Beliefs in the nature of science and responses to socioscientific dilemmas. Science Education, 86(3), 343367. doi:https://doi.org/10.1002/sce.10025.

Zohar, A., \& Nemet, F., (2002). Fostering students' knowledge and argumentation skills through dilemmas in human genetics. Journal of Research in Science Teaching, 39(1), 35-62. doi:https://doi.org/10.1002/tea.10008. 